\title{
Predicting Methane Production Potential of Anaerobic Co-digestion of Swine Manure and Food Waste
}

\author{
JoungDu Shin ${ }^{\dagger}$, SungSu Han, Ki-Cheol Eom, Shihwu Sung ${ }^{1}$, SangWon Park ${ }^{1}$, Hyunook Kim ${ }^{2}$ \\ Department of Environmental Ecology, Agro-Environmental Division, National Institute of Agricultural Science and Technology, RDA, Republic of Korea \\ ${ }^{1}$ Department of Civil, Concentration and Environmental Engineering, Ames, Iowa State University, USA \\ ${ }^{2}$ Department of Environmental Engineering, University of Seoul, Republic of Korea
}

Received February 2008, accepted June 2008

\begin{abstract}
Anaerobic co-digestion of swine manure and food waste for biogas production was performed in serum bottles at 2\% volatile solids(VS) concentration and various mixing ratios of two substrates(swine manure: food waste $=100: 0 \sim 0: 100$ ). Through kinetic mode of surface methodology, the methane production was fitted to a Gompertz equation. The specific methane production potential of swine manure alone was lower than that of food waste. However, maximum methane production potential increased up to $1.09-1.22 \%$ as food waste composition increased up to the $80 \%$. The maximum methane production value of food waste was $544.52 \mathrm{~mL} / \mathrm{g}$ VS. It was observed that the maximum methane production potential of $601.86 \mathrm{~mL} / \mathrm{g}$ VS was found at the mixing ratio of 40:60.
\end{abstract}

Keywords: Anaerobic co-digestion, Gompertz equation, Swine manure, Food waste, Methane production

\section{Introduction}

Due to the limited resources and ever-increasing greenhouse gas emission, fossil fuels should be substituted for renewable bioenergy (United Nation of Framework Convention a Climate Change: UNFCCC). In general, waste management technologies are based on physical, chemical, or biological conversions, including combustion/incineration (gasification), thermo-chemical conversion (crude oil or methanol) and biological conversion (anaerobic digestion). Gasification efficiently recovers the significant amount of energy from manure, but the management of the remaining ash is still problematic because the amount of the produced solid waste is as much as $30 \%$ of the original weight. Moreover, the wet manure with low solid content requires a supplementary fuel to sustain gasification. ${ }^{1)}$ The practicality of conversing methane into methanol from biomass is promising, but yet a few specific technology or researches are available.

Anaerobic digestion is biological means to decompose an organic matter in an oxygen-free environment, and has an advantage of producing a fuel gas $\left(\mathrm{CH}_{4}\right.$ or $\left.\mathrm{H}_{2}\right)$ and odor-free residues which is rich in plant nutrients and can be used as bio-

\footnotetext{
+ Corresponding author

E-mail: jdshin@rda.go.kr

Tel: +82-31-290-0229, Fax: +82-31-290-0206
}

fertilizer.

Food waste and swine manure are the most abundant and problematic organic solid wastes in Korea. The amount of food waste produced in Korea is about 11,000 tons per day, accounting for $23 \%$ of municipal solid wastes. ${ }^{2}$ That of swine waste is about 150,000 tons/day, and approximately $5.7 \%$ of the produced swine waste is disposed by ocean dumping. ${ }^{3)}$ It is the major source of odor production, vermin attraction, toxic gas emission and groundwater contamination, with being collected, transported, and landfill of solid wastes due to their high organic contents (food waste; volatile solid/total solid, 0.8-0.9) and moisture contents (food waste; 77-85\%, swine manure; 67-74\%). However, these wastes might be suitable for fermentative methane production, because one is carbohydrate-rich ${ }^{4)}$ and the other is high in alkalinity.

Co-digestion of swine waste with organic carbon rich wastes has been accepted as an economic and feasible approach to retrofit conventional digesters. ${ }^{5,6)}$ Methane produced by anaerobic digestion of food waste with swine waste can be easily converted to energy for a local community. Despite its potential benefit, successful application of the co-digestion of food waste and swine manure is rarely carried out in Korea. It is mainly because the knowledge on the digester operation is not mature yet (ex. optimum mixing ratio of swine manure and food waste). 
The objective of the current study was to find the relationship between mixing ratio of food waste and swine manure, and methane production using a full quadratic model.

\section{Materials and methods}

\subsection{Seeding Sludge}

Seeding sludge was taken from an anaerobic digester in a local waste treatment plant. Once collected, the seeding sludge was stored in a refrigerator at $4^{\circ} \mathrm{C}$ for one week before analyzing its volatile solids (VS) contents. Then it was pre-heated to $35^{\circ} \mathrm{C}$ for $24 \mathrm{hr}$ and inoculated with substrates. The VS concentration was $2.728 \%$.

\subsection{Substrate}

A mixture of food waste and swine manure was used as substrate in this study. Food waste from a local restaurant was grinded by an electrical blender. Swine manure was collected from a local swine farm. The substrate was loaded into each incubation bottle $(250 \mathrm{~mL})$. The volatile solid (VS) content of the substrates was adjusted at $2 \%$. Physicochemical parameters as $\mathrm{pH}$, TSS, VSS, T-N and T-P were determined according to Standard Methods. ${ }^{7)}$ The Physicochemical characteristics of substrate are presented in Table 1.

Table 1. Physicochemical characteristics of substrate used in this study

\begin{tabular}{lcc}
\hline Parameters & Swine manure & Food waste \\
\hline $\mathrm{pH}(1: 5)$ & 7.6 & 4.5 \\
Electrical Conductivity (mS/cm) & 3.4 & 13.6 \\
Total Solid (\%) & 30.7 & 20.4 \\
Volatile Solid (\%) & 20.5 & 16.3 \\
Total Nitrogen (\%) & 4.0 & 3.0 \\
$\mathrm{NH}_{4}-\mathrm{N}$ (mg/kg) & 565.0 & 682.4 \\
$\mathrm{NO}_{3}-\mathrm{N}$ (mg/kg) & 13.6 & 8.1 \\
Total Phosphorus (\%) & 28.7 & 31.0 \\
\hline
\end{tabular}

\subsection{Digestion Procedures}

The experiment was conducted using $250 \mathrm{~mL}$ of Duran bottles by 3 replications of split plot design. Total six treatments were made; swine manure and food waste were mixed at the ratios of 100: 0(T1), 80: 20(T2), 60: 40(T3), 40: 60(T4), 20: 80(T5) and 0: 100(T6), respectively. Each bottle was added with $8.18 \mathrm{~mL}$ of seeding sludge and appropriate amount of swine manure and food. Subsequently, the headspace of each bottle was flushed with $\mathrm{N}_{2}$ gas for $3 \mathrm{~min}$, degassed $1 \mathrm{hr}$ later with a glass syringe, and sealed tight with a clamp. The bottles were then placed in a shaker at $35^{\circ} \mathrm{C}$ and $100 \mathrm{rpm}$. The amount of biogas production was measured by using $20-200 \mathrm{~mL}$ of a glass syringe. ${ }^{8)}$ At the same time, methane concentration of the produced gases was periodically determined. Methane content in the biogas was measured by a gas chromatography (GC: Varian CP3800) with a thermal conductivity detector and a $1.0 \mathrm{~m} \times 2 \mathrm{~mm}$ stainless steal packed column with $\mathrm{N}_{2}$ gas as a carrier. The temperatures of detector and column were kept at 189 and $40^{\circ} \mathrm{C}$.

\subsection{Kinetic Model}

In many biological fields, the basic knowledge of phenomena is insufficient to build a mechanistic model. In this case, responding to surface methodology, an empirical model or a statistical analysis can be formulated to elucidate basic mechanisms underlying a complex system and thus providing better guidance in process design and control. ${ }^{9)}$ In this study, the effect of mixing ratios of swine manure and food waste to methane production in the anaerobic digester was analyzed using a Gompertz model ${ }^{10)}$ as shown below.

$$
M_{p}=P_{m} \exp \left[-\exp \left\{\frac{R_{m}}{P_{m}}\left(x_{0}-x\right) e+1\right\}\right]
$$

where $M_{p}$ was cumulative methane production (mL), $P_{m}$ was ultimate methane production (mL), $R_{m}$ was methane production rate (mL/day), $x_{0}$ was lag-phase time (days), and $e$ was exponential 1.

All the parameters in the above equation were evaluated by performing regression with a Newtonian algorithm to minimize the sum of the square errors (SSE) between the experiment and estimation using Sigmaplot version 10.0. The goodness of the parameter fit was diagnosed by SSE, correlation coefficient $\left(\mathrm{R}^{2}\right)$, standard errors (SE), 95\% of confidence limits, t-test, and F-test.

\section{Results and Discussions}

\subsection{Biogas Production}

The estimation of the potential biogas production and its methane content are one of the most important aspects in the design of an anaerobic digester.

Biogas production rate during co-digestion of swine manure and food wastes is shown in Fig. 1. Of biogas production, the maximum methane production was observed from 20 to 40 days in all the treatments. However, it was observed that prolonged periods of the higher methane production could be observed from the bottle with higher ratio of food waste to swine waste. This tendency could be attributed to the higher carbon content of food waste.

$\mathrm{CH}_{4}$ and $\mathrm{CO}_{2}$ contents from co-digestion of swine manure and food waste with different mixing ratios are shown in Fig. 2. The methane contents were being increased from 0 to 10 days for T1 and T2, 21 days for T3, 31 days for T4, 36 days for T5 and 40 days for T6. On the other hand, $\mathrm{CO}_{2}$ contents were rapidly increased in the initial period, and then slowly decreased in the all cases. It observed that the slopes of methane content were declined with increasing the mixing rate of food waste to swine manure at initial stage of digestion periods. The average content of methane in the produced biogases was ranged from $58.9 \%$ to $64.1 \%$ during stage state periods. These ranges were slightly low compared to its swine manure only, $65.3 \%$. $^{11)}$ 

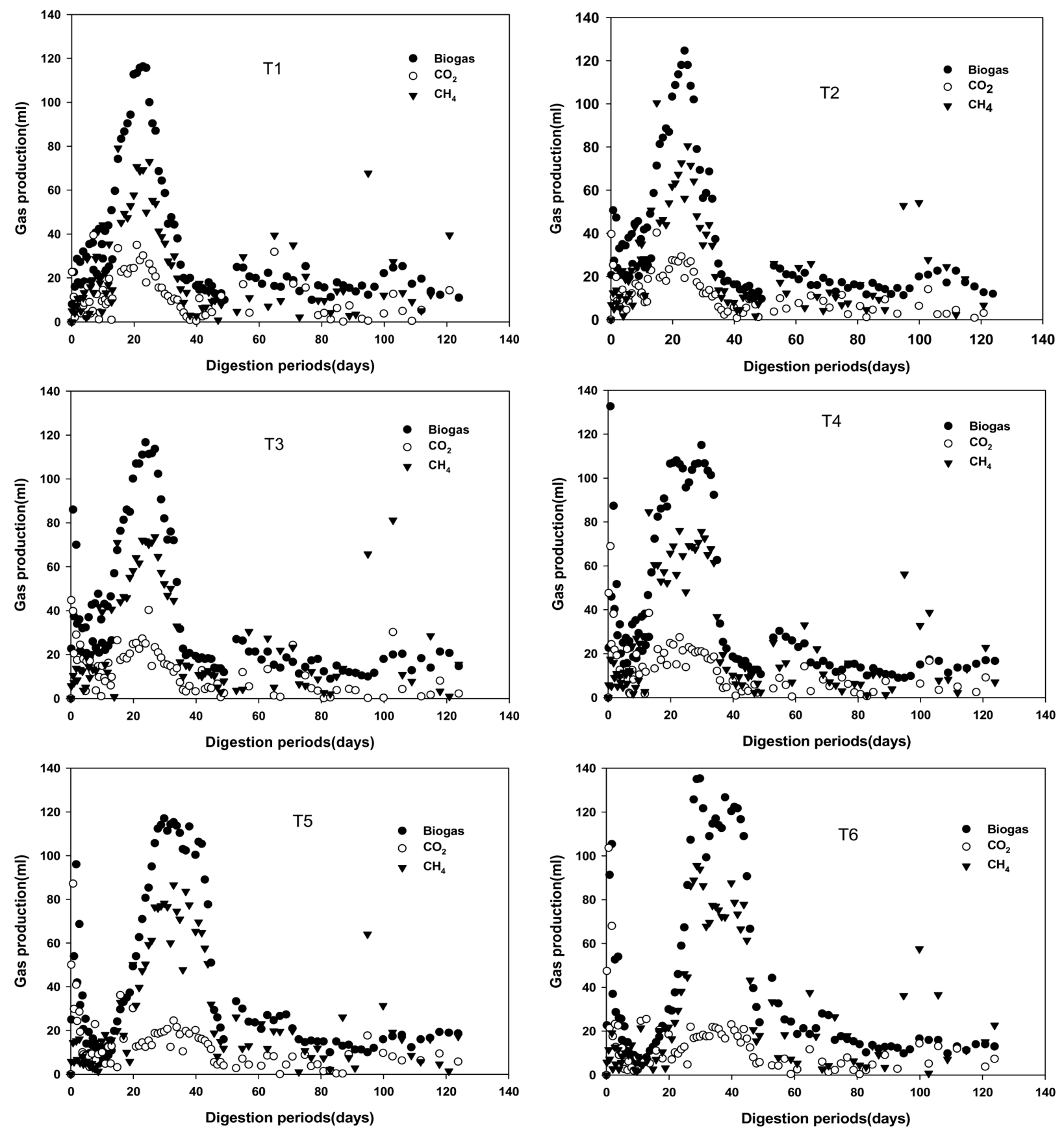

Fig. 1. Effects of mixing ratio of swine manure and food waste on biogas production over digestion periods.

\subsection{Estimation of Methane Production Potential Using the Logistic Regression Model}

The regression model provided in Eq. (1) was applied to fit the methane production profiles and the goodness of each fit was determined using the model $p$ value.

The cumulative methane production curves from the 6 different treatments were well described with Eq. (1). All the model $\mathrm{p}$ values were less than 0.0001 in Table 2, suggesting that the regression model is statistically significant. Although the hydrogen production curve was fitted to a modified Gompertz equation, ${ }^{12)}$ which was used as a suitable model for describing the hydrogen production in a batch system, ${ }^{13-15)}$ it was observed that Gompertz model was also proper to predict the methane production with co-digestion of food waste and swine manure. Fig. 3 illustrates that the maximum methane production potential was found to be higher than $536.54 \mathrm{~mL} / \mathrm{g}$ VS fed in all mixing ratios, but these values were over two fold higher than the reported maximum values, 268, 229 and $213 \mathrm{~mL} / \mathrm{g}$ VS fed, from co-digestion with cow manure and crop residues such as grass, sugar beet top and straw, respectively. ${ }^{16)}$ The maximum methane production potential was $601.86 \mathrm{~mL} / \mathrm{g}$ VS fed as the mixing ratio increased up to 60: 40(swine manure: food waste). The higher methane production from the mixed reactor with swine 



Fig. 2. Effects of the mixing ratios of swine manure and food waste on $\mathrm{CH}_{4}$ and $\mathrm{CO}_{2}$ contents in the produced biogas.



Fig. 3. Fitting result of the Gompertz model to methane production profile. manure and food waste was again attributed to the increased carbon contents. Swine manure showed lower methane production potential than food waste. The maximum value was 492.36 $\mathrm{mL} / \mathrm{g}$ VS fed. Less methane production from swine waste can be attributed to its relatively lower organic contained than food waste.

\subsection{Effects of Mixing Ratios Based on VS $2 \%$ on Digestive Methane Production}

Table 2 shows that each variable of the model was calculated with different treatment for methane production potential. The activity of methane production bacteria would be decreased if 
Table 2. Model parameters identified from regression of the methane production profiles

\begin{tabular}{llllll}
\hline Treat. & Swine manure (\%, VS $2 \%$ basis) & $P_{m}(\mathrm{~mL} \mathrm{CH})$ & $R_{m}(\mathrm{~mL} /$ day $)$ & $X_{0}$ (day) & $\mathrm{R}^{2}$ \\
\hline T1 & 100 & 492.36 & 21.43 & 5.68 & 0.997 \\
T2 & 80 & 566.02 & 26.30 & 5.71 & 0.998 \\
T3 & 60 & 552.09 & 22.96 & 6.62 & 0.998 \\
T4 & 40 & 601.86 & 26.23 & 8.03 & 0.997 \\
T5 & 20 & 536.54 & 21.40 & 17.36 & 0.995 \\
T6 & 0 & 544.52 & 24.29 & 24.29 & 0.995 \\
\hline
\end{tabular}

too much food waste was provided (Table 2 and Fig. 3). It is because methanogenic activity can be affected by the low $\mathrm{pH}$ or high salt contents from the waste. It was appeared that maximum methane production potential found at 40:60 of the waste composition (Table 2).

\section{References}

1. O. S. U., Ohio livestock manure and waster management guide. Bulletin 604, Ohio State University Extension (2000).

2. Ministry of Environment, The state of solid waste generation and treatment in 2001. Seoul, Korea (2002).

3. Ministry of Environment, The state of solid waste generation and treatment in 2005. Seoul, Korea (2005).

4. Han, S.-K., and Shin, H.-S., "Enhanced acidogenic fermentation of food waste in continuous-flow reactor," Waste Manage Res 2002, 20, 110-118 (2002).

5. Lafitte-Trouque, S., and Forster, C. F., "Dual anaerobic codigestion of swage sludge and confectionery waste," Bioresource Technol., 71, 77-81 (2000).

6. Schafter, P. L., and Farrel, J. B., "Advanced anaerobic digestion systems," Water Environ Technol., 12(11), 26-32 (2000).

7. APHA AWWA WEF, Standard methods for the examination of waster and wastewater. 20th ed., APAH, Washington DC (1988).

8. Owen, W. F., Stuckey, D. C., Healy, Jr J. B., Young, L. Y., and McCarty, P. L., "Bioassay for monitoring biochemical methane potential and anaerobic toxicity,” Water Res. 13,
485-493 (1979).

9. Yang, K., Yu, Y., and Hwang, S., "Selective optimization in thermophilic acidogenesis of cheese-whey wastewater to acetic and butyric acids: partial acidification and methanation,” Water Res., 37, 2467-2477 (2003).

10. Momirlan, M., and Veziroglu, T., "Recent directions of world hydrogen production,” Renew Sust. Energy Rev., 3, 219-231 (1999).

11. Chae, K. J., Jang, A. M., Yim, S. K., and Kim, In S., “The effects of digestion temperature and temperature shock on the biogas yields from the mesophilic anaerobic digestion of swine manure," Bioresource technol., 99, 1-6 (2008).

12. Momirlan, M., and Veziroglu, T., "Recent directions of world hydrogen production," Renew Sust Energy Rev., 3, 219-231 (1999).

13. Lay, J.-J., "Biohydrogen generation by mesophilic anaerobic fermentation of microcrystalline cellulose," Biotechnol Bioeng., 74(4), 280-287 (2001).

14. Lee, Y. J., Miyahara, T., and Noike, T., "Effect of iron concentration on hydrogen fermentation," Bioresource Technol., 80, 227-231 (2001).

15. Chen, C-C., Lin, C-Y., and Lin, M-C., "Acid-based enrichment enhances anaerobic hydrogen production process," Appl. Microbiol Biotechnol., 58, 224-228 (2002).

16. Lethtomaki, A., Huttunen, S., and Rintala, J. A., "Laboratory investigation on co-digestion of energy crops and crop residues with cow manure for methane production: Effect of crop to manure ratio," Resources Conservation \& Recycling, 51, 591-609 (2007). 